\title{
Evaluation of Pigeon Pea Lines for Biological Soil Decompaction
}

\author{
Rodolfo Godoy, ${ }^{1}$ Osny Oliveira Santos Bacchi, ${ }^{2}$ Fernando Almeida Moreira, ${ }^{3}$ \\ and Klaus Reichardt ${ }^{2}$ \\ ${ }^{1}$ Embrapa Pecuária Sudeste, Caixa Postal 339, 13560-970 São Carlos, SP, Brazil \\ ${ }^{2}$ Centro de Energia Nuclear na Agricultura, CENA/USP, Caixa Postal 96, 13400-970 Piracicaba, SP, Brazil \\ ${ }^{3}$ Fellow of Environmental Engeneering of FUMEP, Avenida Monsenhor Martinho Salgot 560, \\ 13414-040 Piracicaba, SP, Brazil \\ Correspondence should be addressed to Klaus Reichardt, klaus@cena.usp.br
}

Received 26 June 2009; Revised 26 November 2009; Accepted 10 December 2009

Recommended by Bernd Lennartz

Soil decompaction is generally achieved through mechanical cultivation practices; however biological processes can significantly add to this process through root growth, development, and later senescence. This study was carried out in Piracicaba, SP, Brazil and had the purpose of selecting, among forty one pure pigeon pea lines, the most efficient genotypes that promote soil decompaction by roots penetrating compacted soil layers. Utilizing artificially compacted $30 \mathrm{~mm}$ high soil blocks, in a series of experiments, these lines were compared to the cultivar Fava Larga taken as a standard. Three lines were preliminarily selected out of the initial group, and afterwards, in more detailed screenings by monitoring soil resistance to penetration and also evaluating the behavior of Tanzania grass plants seeded after pigeon pea, two of them, g5-94 and g8-95, were selected as possessing the most fit root system to penetrate compacted soil layers.

Copyright ( 2009 Rodolfo Godoy et al. This is an open access article distributed under the Creative Commons Attribution License, which permits unrestricted use, distribution, and reproduction in any medium, provided the original work is properly cited.

\section{Introduction}

Adverse effects of soil compaction on crop production have been recognized for many years [1] and although being a relatively common problem in crop cultivation, it can also occur in pastures [2] and even in forests [3]. Several alternatives are used to minimize soil compaction problems, among which deep plowing operations are the most commonly adopted procedures to promote soil decompaction. Another way is the utilization of appropriate plant species whose roots, besides penetrating compacted soil layers, leave micropores that will facilitate the penetration of water and roots of other plants [4]. Several reports present results of species comparisons in this aspect [5-7]. Camargo and Alleoni [4] report that, among other species, very good results have been obtained with pigeon pea. Alvarenga et al. [7] verified that pigeon pea plant roots were not affected by soil densities above $1.35 \mathrm{Mg} \mathrm{m}^{-3}$ and Silva and Rosolem [8] concluded that soybean yields were improved in highly compacted soils when cultivated after a pigeon pea crop. Cintra and Mielniczuk [5] concluded that there seems to be variability within individuals of the same species in the capacity of promoting soil decompaction. This variability could be used for selecting plants with that specific characteristic.

This research had the objective of testing forty pigeon pea lines as to their ability in penetrating artificially compacted soil layers, with the purpose of providing reliable data for field tests that will lead to the release of new cultivars specially recommended for soil decompaction. The lines used were previously selected for favorable agronomic characteristics $[9,10]$. After selection they were purified through selfpollination for several generations.

\section{Material and Methods}

Root penetration studies were carried out in a series of experiments in a greenhouse equipped with a microsprinkler irrigation system, located at Piracicaba, SP, Brazil $\left(22^{\circ} 43^{\prime}\right.$ $31^{\prime \prime} \mathrm{S}$ and $47^{\circ} 38^{\prime} 57^{\prime \prime} \mathrm{W}, 580 \mathrm{~m}$ above sea level). Using $2 \mathrm{~mm}$ sieved soil samples, collected from the $0-0.2 \mathrm{~m}$ top soil layer 
of a Rhodic Hapludox (Soil Survey Staff, 1993), compacted soil cores of $30 \mathrm{~mm}$ height were prepared in PVC cylinders $90 \mathrm{~mm}$ high and $143 \mathrm{~mm}$ internal diameter. Disturbed soil samples were compacted with a piston pressure device, using wet samples in such amounts to obtain soil blocks of $30 \mathrm{~mm}$ height with $30 \%$ of water v/v and bulk density of $1.6 \mathrm{M} \mathrm{gm}^{-3}$. The empty space of the PVC cylinders was thereafter filled with a $30 \mathrm{~mm}$ vermiculite layer placed over the compressed blocks. The vermiculite layer consists of the commercially found growth media used to germinate seedlings before transplant, into which the pigeon seedlings were transplanted. The cylinders were then placed over plastic trays also with a humid vermiculite layer of $20 \mathrm{~mm}$ height and taken to the greenhouse for seedling transplant. In the greenhouse, nine small holes were made in the upper vermiculite layer to plant uniform seedlings of pigeon pea (Cajanus cajan (L.) Millsp) with roots of about $20 \mathrm{~mm}$. Similar sets with the cultivar Fava Larga were used as control.

In such a system roots would develop freely in the top vermiculite layer and, when reaching the compacted soil block, would or not penetrate the soil. The vermiculite block below the compacted soil would permit to observe the amount of roots transpassing the compacted layer.

The trials were installed in May 17, 22, and 29, and June 5 and 12, 2006. A randomized block experimental design was used in each trial, with five replicates. Two weeks after planting, plants were harvested to evaluate shoot and root dry matter yields, separating roots of the upper and lower vermiculite layers as well as in the compacted soil blocks. In order to monitor the soil water content and penetration resistance without disturbing the soil in the cylinders with plants, identical sets of compacted blocks were mounted without plants which were periodically weighted and had their penetration resistance evaluated with a field digital penetrometer (PNT-2000, DLG Automação, made in Brazil). The field penetrometer was attached to a device to facilitate its operation. These procedures and equipments are described in detail in Godoy et al. [11].

Pigeon pea lines were evaluated in five experiments.

Experiment 1. g1m-95, g3-94, g8-95, g9m-97, and g10-94.

Experiment 2. g19m-95, g29m-94, g40-95, g48-95, g57-95, g59-95, g108-99, g109-99, g119-99, g121-99, and g123-99.

Experiment 3. g27b-94, g29b-94, g66-95, g137-99, g138-99, g142-95, g146-97, g149-99, g167-97, and g186-99.

Experiment 4. g5-94, g6-95, g17c-94, g18-95, g19b-94, g3994, g47-94, g58-95, g118-97, g124-95, and g127-97.

Experiment 5. g101-97, g168-97, g184-97, g154-97, and again, g5-94.

The key codes used above stand for "g" for guandu (pigeon pea name in Potuguese); the following number stands for the order of arrival of the seeds to the institute of the first author, Embrapa (seeds came from several research centers in Brazil and India); the letters " $m$ " and " $b$ " stand for seed color in the original accession ( $m$ for brown and $b$ for white); "95" stand for the year the pure line was obtained after a selection process within the original accessions. More details regarding these procedures can be found in the work by Godoy et al. [9, 10].

In these first five experiments sets of compacted cylinders without plants were periodically weighted and had their resistance to penetration measured which made it possible to control well the irrigation water. The frequency and volumes of water applied by irrigation were considered adequate to keep the moisture of the compacted soil blocks constant.

The best three lines in terms of amounts of roots trespassing the compacted soil layers and amounts of roots present in the vermiculite below the compacted blocks were then submitted to new trials (experiments 6 to 8), all installed as described for the first series of five experiments, except for experiment 6 , in which sand was used instead of vermiculite in the upper layer. The intent of using sand instead of vermiculite was to make the harvest and the cleaning of the upper part of the plants easier. Since this was not achieved by using sand, vermiculite was again used in the other trials. Soil blocks were compacted in these experiments up to a bulk density of $1.55 \mathrm{Mg} \mathrm{m}^{-3}$ and the same control; the Fava Larga cultivar was used. Experiment 6 was installed on July 17 , with fifteen replications, in a randomized block design. Control sets were also prepared for soil moisture monitoring through weighting and for measuring soil resistance to penetration as described above. Three weeks after planting, the experiment was harvested and the same determinations previously described were performed.

In the last week of August, experiment 7 was installed with the same selected three pigeon pea lines, but using again vermiculite in the upper layer. A randomized block design was used again, with fifteen replicates. Five blocks (replicates) were used to evaluate the development of the pigeon pea plants and the other ten had the purpose of evaluating the development of Tanzania grass (Panicum maximum Jacq.) planted on the blocks that had previously pigeon pea plants, in order to appreciate the various treatments of the compacted soil condition. Another treatment was added to these blocks, with no pigeon pea plants (blank). One month after the planting date, the first five blocks had their resistance to penetration determined on the compact blocks and the plants were harvested as previously described. On the ten other blocks, the aerial parts of the plants were harvested and deposited over the compact soil layer, once the upper vermiculite layer had been removed. Twenty days later, these sets were seeded with approximately 80 pure and viable seeds of the Tanzania grass that were covered with a layer of $5 \mathrm{~mm}$ of soil. Forty days later the Tanzania plants were harvested as previously described and the resistance to penetration of the compacted soil layer was determined. Control sets were kept as before. Experiment 8 repeated experiment 7 using only the two best (in terms of root development through the compacted blocks and penetrometer readings) pigeon pea lines, three blocks for evaluating plant development and four blocks for evaluating the Tanzania grass development.

In all experiments, dry matter yields of the plant parts of the lines were compared to the control (cultivar Fava Larga) by the Dunnett test and all treatments were compared among 
themselves by the Duncan test, both at the five percent probability level.

To verify uniformity of the compacted blocks, four blocks were prepared, two with a bulk density of $1.55 \mathrm{Mg} \mathrm{m}^{-3}$ and the others with a density of $1.6 \mathrm{Mg} \mathrm{m}^{-3}$, all of them with volumetric water content of $30 \%$. In order to better evaluate the soil compaction inside the blocks without damaging them, tomographic images of these blocks were obtained through a first generation tomograph, having a gamma ray ${ }^{137} \mathrm{Cs}$ source and a 3 in $\times 3$ in $\mathrm{NaI}(\mathrm{Tl})$ scintillation crystal detector coupled to a photomultiplier [12]. The images were acquired from vertical planes to allow distribution analyses of the soil densities in both directions, vertical and horizontal.

\section{Results and Discussion}

Small differences were observed between initial and final cylinder weights in all experiments. On the other hand, in experiments 1,2 , and 5 , great reductions in soil penetration resistance were observed, which probably were caused by the holes made by the penetrometer needle that may have caused water infiltration. Such problems were also reported by Alvarenga et al. [7], who used penetration pressures of 1.9 MPa for soils with a bulk density of $1.4 \mathrm{Mg} \mathrm{m}^{-3}$.

Dry matter yields of the aerial parts of the plants and roots in the three layers (top vermiculite layer, compacted soil block, bottom vermiculite layer) for experiments 1 to 5 are shown in Table 1. Root dry matter yields in the compacted soil layer can be considered as the most important variable to demonstrate the ability of the lines to penetrate highly compacted soil layers. In this case, the analysis of variance showed differences among the genotypes in all experiments, except in experiment number 3 . The high coefficients of variation $(\mathrm{CV})$ found for this parameter are in accordance with De Maria et al. [13] that consider that the interpretation of root density data is difficult due to the great variability among replications.

The Duncan test was used mainly to classify the results and the Dunnet test to compare the results of each line against the control.

In the compacted soil layer of experiment 1, the g895 line dry matter yield was significantly higher than the control, by the Dunnett test $(P<.05)$. This difference was also detected by the Duncan test $(P<.05)$. Its dry matter yield in the compacted soil block was $144 \%$ higher in relation to the control, and for this reason this line was selected for further tests.

In experiment 2 no statistical differences were found. In experiments 3 and 5 , the control was the genotype of best performance. In experiment 4, g5-94 and g124-94 lines yielded $26 \%$ more than the control, but with no statistical difference. Probably, the lack of statistical differences was due to the high variation coefficients. Considering this and also the high values of penetration resistance of the compacted soil layer, these two lines were also selected for further testing. In experiment 5, the line g5-95 confirmed its superior performance, presenting a result $12 \%$ superior in relation to the Fava Larga cultivar.

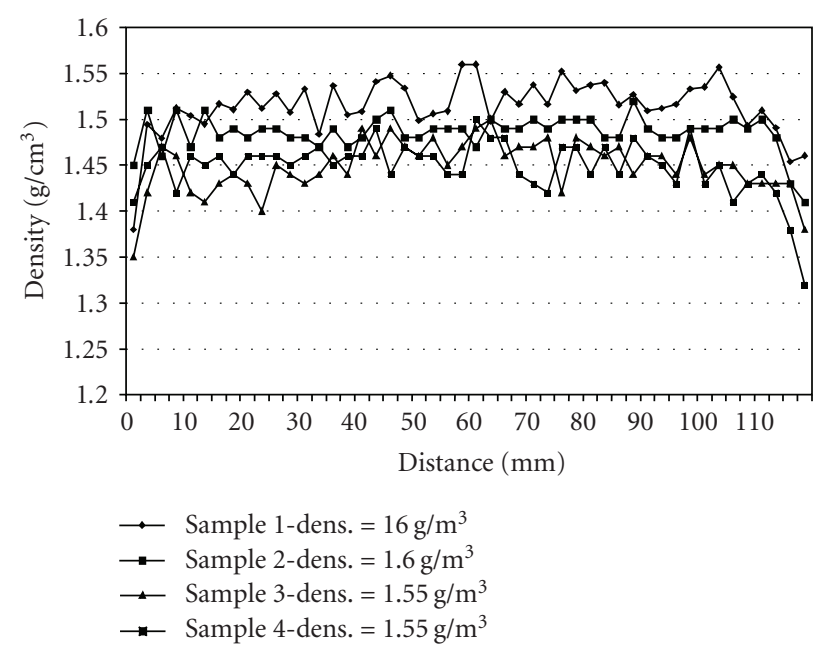

FIGURE 1: Horizontal variation of soil density in artificially compacted soil blocks.

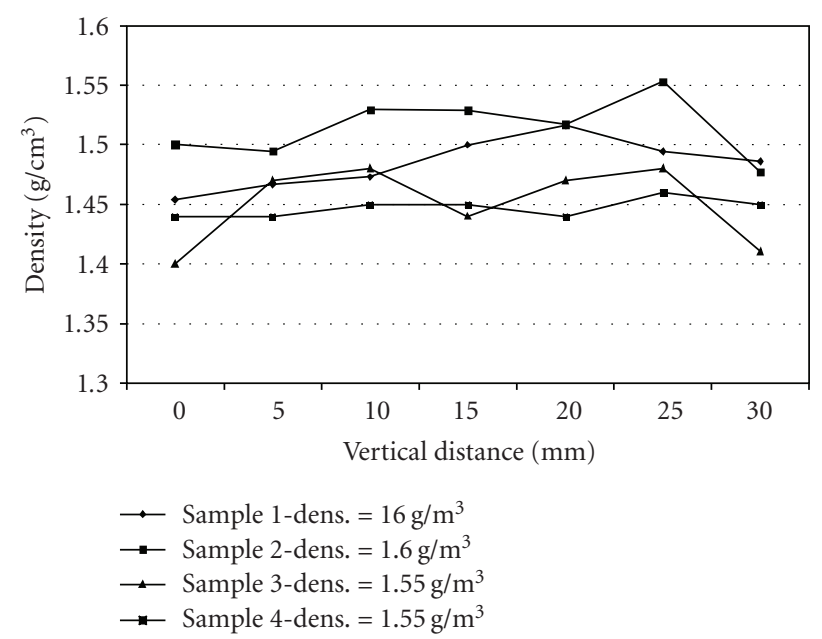

FIGURE 2: Vertical variation of soil density in artificially compacted soil blocks.

In experiment 6 with the best three lines-g5-95, g8-95, and g124-95-in which sand was used in the upper growth layer during the growth phase of the plants, the soil moisture was constant, but the average resistance of the blocks to penetration varied from $3.8 \mathrm{MPa}$ down to $1.6 \mathrm{MPa}$, probably due to water infiltration through the sand layer. It was therefore decided to interrupt the experiment and harvest all sets, including those that would receive the Tanzania grass plants. The results are presented on Table 2. Although the variation coefficients were high, the g5-94 line had the best root yields in the compact soil layer and in the lower sand layer.

In experiment 7 with the three lines, vermiculite was used again in the upper growth layer. The employed methodology was efficient for the maintenance of the soil moisture, but not for soil resistance to penetration measurements. This was probably caused by water penetration through the holes made by the penetrometer needle and by the lack of roots 
TABLE 1: Dry matter weights of the aerial part of the plants and of the roots in the upper and lower vermiculite layers and in the compacted soil layer, of forty pigeon pea genotypes and of the Fava Larga cultivar.

\begin{tabular}{|c|c|c|c|c|c|c|c|c|}
\hline & \multicolumn{8}{|c|}{ Dry matter weights (mg per cylinder) } \\
\hline & \multirow{2}{*}{\multicolumn{2}{|c|}{ Aerial part }} & \multicolumn{6}{|c|}{ Roots } \\
\hline & & & \multicolumn{2}{|c|}{ Upper vermiculite layer } & \multicolumn{2}{|c|}{ Compacted soil block } & \multicolumn{2}{|c|}{ Lower vermiculite layer } \\
\hline \multirow{8}{*}{ Experiment 1} & g1m-95 & $270^{a *}$ & g9m-97 & $1355^{a}$ & g8-95 & $39^{a}$ & g1m-95 & $28^{a}$ \\
\hline & g8-95 & $232^{a b}$ & g8-95 & $1169^{a b}$ & g9m-97 & $19^{b}$ & g8-95 & $22^{a}$ \\
\hline & g9m-97 & $211^{b c}$ & g10-94 & $1073^{a b}$ & g10-94 & $18^{b}$ & g3-94 & $18^{a}$ \\
\hline & g3-94 & $205^{b c}$ & g3-94 & $1002^{b}$ & Fava Larga & $16^{b}$ & g9m-97 & $17^{a}$ \\
\hline & Fava Larga & $199^{b c}$ & g1m-95 & $952^{b}$ & g1m-95 & $13^{b}$ & Fava Larga & $16^{a}$ \\
\hline & g10-94 & $174^{c}$ & Fava Larga & $878^{b}$ & g3-94 & $12^{b}$ & g10-94 & $15^{a}$ \\
\hline & CV (\%) & 22,6 & CV (\%) & 26,8 & CV (\%) & 97,3 & CV (\%) & 123,1 \\
\hline & Mean & 215 & Mean & 1071 & Mean & 19 & Mean & 19 \\
\hline \multirow{14}{*}{ Experiment 2} & g121-99 & $366^{a}$ & g29m-94 & $1571^{a}$ & g29m-94 & $15^{a}$ & & \\
\hline & g48-95 & $352^{a b}$ & g40-95 & $1024^{b}$ & Fava Larga & $13^{a b}$ & & \\
\hline & g57-95 & $307^{a b c}$ & g48-95 & $952^{b c}$ & g129-99 & $10^{a b c}$ & & \\
\hline & g19m-95 & $295^{a b c}$ & g57-95 & $861^{b c}$ & g48-95 & $8^{b c d}$ & & \\
\hline & g129-99 & $279^{b c}$ & Fava Larga & $812^{b c d}$ & g109-99 & $8^{b c d}$ & & \\
\hline & g29m-94 & $263^{c d}$ & g19m-95 & $730^{b-e}$ & g121-99 & $7^{b c d}$ & & \\
\hline & g59-95 & $256^{c d}$ & g121-99 & $677^{b-f}$ & g119-99 & $7^{c d}$ & & \\
\hline & g40-95 & $242^{c d}$ & g129-99 & $631^{c-f}$ & g57-95 & $6^{c d}$ & & \\
\hline & Fava Larga & $231^{c d}$ & g119-99 & $511^{d e f}$ & g108-99 & $6^{c d}$ & & \\
\hline & g108-99 & $192^{c d}$ & g59-95 & $468^{\operatorname{def}}$ & g19m-95 & $6^{c d}$ & & \\
\hline & g109-99 & $142^{e}$ & g108-99 & $386^{e f}$ & g40-95 & $5^{c d}$ & & \\
\hline & g119-99 & $117^{e}$ & g109-99 & $367^{f}$ & g59-95 & $4^{d}$ & & \\
\hline & CV (\%) & 20,4 & CV (\%) & 24,4 & CV (\%) & 50,4 & & \\
\hline & Mean & 254 & Mean & 750 & Mean & 8 & & \\
\hline \multirow{13}{*}{ Experiment 3} & g29b-94 & $511^{a}$ & g27b-94 & $1025^{a}$ & Fava Larga & $35^{a}$ & g146-97 & $1^{a}$ \\
\hline & Fava Larga & $507^{a}$ & g29b-94 & $973^{a}$ & g66-95 & $29^{a b}$ & g29b-94 & $1^{a}$ \\
\hline & g186-99 & $421^{a}$ & Fava Larga & $852^{a b}$ & g137-99 & $21^{a b}$ & g186-99 & $1^{a}$ \\
\hline & g27b-94 & $416^{a}$ & g66-95 & $759^{b c}$ & g27b-94 & $20^{a b}$ & g27b-94 & $0^{a}$ \\
\hline & g66-95 & $407^{a}$ & g149-99 & $704^{b c d}$ & g146-97 & $19^{a b}$ & g138-99 & $0^{a}$ \\
\hline & g149-99 & $360^{a}$ & g146-97 & $626^{b c d}$ & g149-99 & $18^{a b}$ & g66-95 & $0^{a}$ \\
\hline & g138-99 & $347^{a}$ & g137-99 & $563^{c d e}$ & g138-99 & $16^{a b}$ & g149-99 & $0^{a}$ \\
\hline & g142-95 & $329^{a}$ & g186-99 & $507^{d e}$ & g167-97 & $15^{b}$ & g142-95 & $0^{a}$ \\
\hline & g137-99 & $309^{a}$ & g138-99 & $485^{d e}$ & g29b-94 & $13^{b}$ & Fava Larga & $0^{a}$ \\
\hline & g146-97 & $292^{a}$ & g142-95 & $481^{d e}$ & g142-95 & $12^{b}$ & g137-99 & $0^{a}$ \\
\hline & g167-97 & $292^{a}$ & g167-97 & $407^{e}$ & g186-99 & $11^{b}$ & g167-97 & $0^{a}$ \\
\hline & CV (\%) & 35,9 & CV (\%) & 20,9 & CV (\%) & 65,1 & CV (\%) & 211,5 \\
\hline & Mean & 381 & Mean & 671 & Mean & 19 & Mean & 0 \\
\hline \multirow{14}{*}{ Experiment 4} & g118-97 & $240^{a}$ & g5-94 & $2360^{a}$ & g5-94 & $19^{a}$ & g58-95 & $3^{a}$ \\
\hline & g47-94 & $224^{a b}$ & g39-94 & $2029^{a}$ & g124-95 & $19^{a b}$ & g124-95 & $1^{a}$ \\
\hline & g124-95 & $224^{a b}$ & g18-95 & $1167^{b}$ & Fava Larga & $15^{a b c}$ & g5-94 & $0^{a}$ \\
\hline & g6-95 & $218^{a b}$ & g47-94 & $1149^{b}$ & g58-95 & $14^{a b c}$ & g118-97 & $0^{a}$ \\
\hline & Fava Larga & $217^{a b c}$ & g19b-94 & $911^{b c}$ & g39-94 & $12^{a b c}$ & g47-94 & $0^{a}$ \\
\hline & g39-94 & $169^{b c d}$ & g6-95 & $832^{b c}$ & g19b-94 & $10^{a b c}$ & g19b-94 & $0^{a}$ \\
\hline & g5-94 & $153^{b c d}$ & g124-95 & $759^{c}$ & g118-97 & $10^{b c}$ & g127-97 & $0^{a}$ \\
\hline & g19b-94 & $146^{c d}$ & Fava Larga & $726^{c}$ & g18-95 & $9^{c}$ & g39-94 & $0^{a}$ \\
\hline & g127-97 & $135^{c d}$ & g127-97 & $623^{c}$ & g17c-94 & $7^{c}$ & g17c-94 & $0^{a}$ \\
\hline & g17c-94 & $135^{c d}$ & g58-95 & $620^{c}$ & g6-95 & $7^{c}$ & g18-95 & $0^{a}$ \\
\hline & g58-95 & $129^{d}$ & g118-97 & $565^{c}$ & g127-97 & $6^{c}$ & Fava Larga & $0^{a}$ \\
\hline & g18-95 & $127^{d}$ & g17c-94 & $524^{c}$ & g47-94 & $6^{c}$ & g6-95 & $0^{a}$ \\
\hline & CV (\%) & 28,0 & CV (\%) & 21,0 & CV (\%) & 50,4 & CV (\%) & 399,0 \\
\hline & Mean & 176 & Mean & 1055 & Mean & 11 & Mean & 0 \\
\hline
\end{tabular}


TABLE 1: Continued.

\begin{tabular}{|c|c|c|c|c|c|c|c|}
\hline & \multicolumn{7}{|c|}{ Dry matter weights (mg per cylinder) } \\
\hline & \multirow{2}{*}{\multicolumn{2}{|c|}{ Aerial part }} & \multicolumn{5}{|c|}{ Roots } \\
\hline & & & \multicolumn{2}{|c|}{ Upper vermiculite layer } & \multicolumn{2}{|c|}{ Compacted soil block } & Lower vermiculite layer \\
\hline \multirow{8}{*}{ Experiment 5} & g101-97 & $262^{a}$ & g5-94 & $1497^{a}$ & g5-94 & $16^{a}$ & \\
\hline & g5-94 & $222^{a}$ & g168-97 & $669^{b}$ & Fava Larga & $14^{a}$ & \\
\hline & Fava Larga & $222^{a}$ & g184-97 & $664^{b}$ & g101-97 & $14^{a}$ & \\
\hline & g168-97 & $222^{a}$ & Fava Larga & $649^{b}$ & g154-97 & $9^{b}$ & \\
\hline & g184-97 & $200^{a}$ & g101-97 & $603^{b}$ & g168-97 & $7^{b}$ & \\
\hline & g154-97 & $194^{a}$ & g154-97 & $410^{b}$ & g184-97 & $7^{b}$ & \\
\hline & $\mathrm{CV}(\%)$ & 22,7 & $\mathrm{CV}(\%)$ & 53,3 & $\mathrm{CV}(\%)$ & 31,1 & \\
\hline & Mean & 220 & Mean & 755 & Mean & 10 & \\
\hline
\end{tabular}

* In each experiment, means followed by different letters, in each column, are statistically different, by the Duncan test $(P<.05)$. CV: coefficient of variation.

TABLE 2: Dry matter weights of the aerial part of the plants and of roots in the upper and lower sand layers and in the compact soil layer of experiment 6 .

\begin{tabular}{|c|c|c|c|c|c|c|c|}
\hline \multicolumn{2}{|c|}{ Aerial part } & \multicolumn{2}{|c|}{ Upper sand layer } & \multicolumn{2}{|c|}{ Compact soil block } & \multicolumn{2}{|c|}{ Lower sand layer } \\
\hline g5-94 & $685^{a * a *}$ & Fava Larga & $735^{a}$ & g5-94 & $142^{a}$ & g5-94 & $477^{a}$ \\
\hline g124-95 & $493^{b}$ & g8-95 & $664^{a}$ & Fava Larga & $102^{b}$ & g124-95 & $424^{a b}$ \\
\hline Fava Larga & $427^{b}$ & g124-95 & $561^{a}$ & g124-95 & $94^{b}$ & g8-95 & $178^{b c}$ \\
\hline g8-95 & $393^{b}$ & g5-94 & $515^{a}$ & g8-95 & $78^{b}$ & Fava Larga & $145^{c}$ \\
\hline Mean & 501 & Mean & 619 & Mean & 105 & Mean & 306 \\
\hline $\mathrm{CV}(\%)$ & 34,8 & $\mathrm{CV}(\%)$ & 72,6 & $\mathrm{CV}(\%)$ & 36,8 & $\mathrm{CV}(\%)$ & 114,5 \\
\hline
\end{tabular}

${ }^{*}$ Means followed by different letters, in each column, are statistically different, by the Duncan test $(P<.05)$. CV: coefficient of variation.

to remove water in that layer. On the other hand, when blocks 1 to 5 were harvested, the average resistance to penetration was $14.6 \mathrm{MPa}$ and the statistical analysis showed that the replicates with the Fava Larga cultivar had an average resistance to penetration of $17.0 \mathrm{MPa}$, significantly higher (Duncan, $P<.05$ ) than that of the g8-95 line, of 12.4 MPa. During the second phase, the Tanzania plants were harvested, although the average soil resistance to penetration was close to the first value of $12.2 \mathrm{MPa}$ and the coefficient of variation increased from 19\%, when the pigeon pea plants were harvested to $38 \%$ at the end of the experiment.

In experiment 7 , the average soil resistance to penetration increased more than $10 \mathrm{MPa}$ in the sets with plants, when compared to the initial values of the sets without plants. These high resistances certainly affected root development, making it difficult to obtain high root dry matter yield, confirming observations made by De Maria et al. [13].

The results of plant aerial part and root dry matter are shown in Table 3 for experiment 7. The g5-94 line was superior in relation to the control by the Dunnett test, for dry weight of the aerial part and roots in the upper vermiculite layer and compacted soil blocks. For dry weights of the aerial parts and roots in the upper vermiculite layer, g8-95 was also superior to the control, by the Dunnett test. These results indicate clear superiority of the g5-94 line over the Fava Larga cultivar.

Data analyse of the dry matter yields of the Tanzania grass in experiment 7 were not conclusive (Table 4). The Dunnett test did not detect any significant difference when the three lines were compared to the Fava Larga cultivar or with the replications that did not have pigeon pea plants previously (blanks). In general, the variation coefficients were very high, probably due to the extended of time spent for the experiment, which caused an increase in soil penetration resistance of the various sets.

In experiment 8 , when the pigeon pea and the Tanzania grass plants were harvested, the soil penetration resistance was measured in all sets. At first, the overall average was 12.6 MPa and the coefficient of variation was $20.7 \%$. The average resistance to penetration varied from 13.2 MPa for the sets that had the g5-94 line to 11.6 MPa for those with the Fava Larga cultivar, without statistical differences. When the Tanzania plants were harvested, the replicates that previously had the lines g5-94 and g8-95 had in general values for soil resistance to penetration statistically smaller than those that had the Fava Larga cultivar roots and those that were not previously planted. However, the coefficients of variation were very high and much higher than those obtained when the pigeon pea plants were harvested. It can be concluded that the longer the sets remain in the greenhouse, the greater the problems found to evaluate root development, due to differences on water penetration in the compact blocks, causing them to have different resistances along the time.

Dry weight results found when the pigeon pea plants were harvested, in experiment 8 , are presented in Table 4 . Although the Duncan test had not revealed statistical differences, the two lines numerically overcame the control sets in all criteria. Besides that, the Dunnett test showed that both lines were statistically superior to the Fava Larga 
TABLE 3: Dry matter weights of the aerial part of the plants and of the roots in the upper and lower vermiculite layers and in the compacted soil layer, of pigeon pea plants and of Tanzania grass plants planted after the pigeon pea harvest of experiment 7 .

\begin{tabular}{|c|c|c|c|c|c|}
\hline Experiment & Genotype & Aerial part & Upper Vermiculite layer & Compacted soil block & Lower vermiculite layer \\
\hline \multirow[t]{6}{*}{ Pigeon pea } & g5-94 & $839^{a *}$ & $343^{a}$ & $37^{b}$ & $117^{a}$ \\
\hline & g8-95 & $860^{a}$ & $310^{a b}$ & $63^{a}$ & $116^{a}$ \\
\hline & g124-95 & $717^{a b}$ & $260^{b c}$ & $33^{b}$ & $114^{a}$ \\
\hline & Fava Larga & $385^{b}$ & $219^{c}$ & $16^{b}$ & $1^{a}$ \\
\hline & CV (\%) & 34,7 & 18,8 & 44,9 & 99,5 \\
\hline & Mean & 700 & 283 & 37 & 87 \\
\hline \multirow[t]{7}{*}{ Tanzania } & g5-94 & $1443^{a a}$ & $199^{a}$ & $124^{a}$ & $365^{a}$ \\
\hline & g8-95 & $942^{a}$ & $175^{a}$ & $83^{a b}$ & $213^{a}$ \\
\hline & g124-95 & $766^{a}$ & $164^{a}$ & $67^{b}$ & $196^{a}$ \\
\hline & Fava Larga & $1435^{a}$ & $232^{a}$ & $128^{a}$ & $325^{a}$ \\
\hline & Blank & $1308^{a}$ & $171^{a}$ & $103^{a b}$ & $300^{a}$ \\
\hline & CV (\%) & 66,6 & 59,8 & 49,1 & 73,2 \\
\hline & Mean & 1185 & 189 & 102 & 281 \\
\hline
\end{tabular}

${ }^{*}$ Means followed by different letters, in each experiment and in each column, are statistically different, by the Duncan test $(P<.05)$. CV: coefficient of variation.

TABLE 4: Dry matter yields of plant components of three pigeon pea genotypes and of components of Tanzania plants planted after pigeon pea harvest of experiment 8 .

\begin{tabular}{|c|c|c|c|c|c|}
\hline Experiment & Genotype & Aerial part & Upper vermiculite & Compact soil & Lower vermiculite \\
\hline \multirow[t]{5}{*}{ Pigeon pea } & g5-94 & $1513^{a}$ & $451^{a}$ & $89^{a}$ & $201^{a}$ \\
\hline & g8-95 & $1280^{a}$ & $438^{a}$ & $66^{a}$ & $159^{a}$ \\
\hline & Fava Larga & $885^{a}$ & $276^{a}$ & $39^{a}$ & $115^{a}$ \\
\hline & $\mathrm{CV}(\%)$ & 29,2 & 31,7 & 33,5 & 35,2 \\
\hline & Mean & 1226 & 388 & 65 & 158 \\
\hline \multirow[t]{6}{*}{ Tanzania } & g5-94 & $603^{a}$ & $47^{a}$ & $98^{a}$ & $70^{a}$ \\
\hline & g8-95 & $548^{a}$ & $25^{a}$ & $70^{a}$ & $61^{a}$ \\
\hline & Fava Larga & $513^{a}$ & $51^{a}$ & $55^{a}$ & $73^{a}$ \\
\hline & Blank & $7^{a}$ & $4^{a}$ & $0^{a}$ & $0^{a}$ \\
\hline & CV (\%) & 115,1 & 87,5 & 57,6 & 108,3 \\
\hline & Mean & 417 & 32 & 56 & 51 \\
\hline
\end{tabular}

${ }^{*}$ Means followed by different letters, in each experiment and in each column, are statistically different, by the Duncan test $(P<.05)$. CV: coefficient of variation.

cultivar, when root dry weight in the compacted soil blocks was evaluated.

Table 4 also shows the average dry weight of the components of the Tanzania grass plants, in experiment 8 . No statistical differences were found, probably due to the high coefficient of variation caused by the lack of uniformity within replications, which is a great problem in this kind of experimentation. However, numerically both lines had better performance than the Fava Larga cultivar, when root dry weight in the compacted soil blocks was evaluated. The replicates that had not received pigeon pea plants did not have Tanzania grass roots in the compact soil layer, confirming the importance of this leguminous plant for soil decompaction.

Tomographic images were performed in two pairs of blocks with densities of 1.55 and $1.6 \mathrm{Mg} \mathrm{m}^{-3}$ each pair. From these tomographic images, graphs were built showing horizontal and vertical distributions of soil bulk densities. For the blocks of $1.6 \mathrm{Mg} \cdot \mathrm{m}^{-3}$, horizontally, the average densities were 1.51 and $1.49 \mathrm{Mg} \cdot \mathrm{m}^{-3}$, with standard deviations of 0.03 and 0.02 , maximum values of 1.56 and $1.52 \mathrm{Mg} \cdot \mathrm{m}^{-3}$, and minimum values of 1.38 and $1.41 \mathrm{Mg} \cdot \mathrm{m}^{-3}$. For the other pair of blocks, the obtained values were practically identical: average density of $1.45 \mathrm{Mg} \cdot \mathrm{m}^{-3}$, with a standard deviation of 0.03 , maximum value of $1.50 \mathrm{Mg} \cdot \mathrm{m}^{-3}$, and minimum values of 1.35 and $1.32 \mathrm{Mg} \cdot \mathrm{m}^{-3}$. Vertically, the $1.6 \mathrm{Mg} \cdot \mathrm{m}^{-3}$ blocks had average values of 1.51 and $1.48 \mathrm{Mg} \cdot \mathrm{m}^{-3}$, with standard deviations of 0.03 and 0.01 , maximum values of 1.55 and $1.48 \mathrm{Mg} \cdot \mathrm{m}^{-3}$, and minimum values of 1.40 and $1.44 \mathrm{Mg} \cdot \mathrm{m}^{-3}$. The other two blocks presented average value of $1.45 \mathrm{Mg} \cdot \mathrm{m}^{-3}$, with standard deviations of 0.03 and 0.01 , maximum values of 1.48 and $1.46 \mathrm{Mg} \cdot \mathrm{m}^{-3}$, and minimum values of 1.40 and $1.44 \mathrm{Mg} \cdot \mathrm{m}^{-3}$. Figures 1 and 2 show vertical and horizontal variations of soil bulk density. The estimated densities obtained by tomographical images were slightly lower than those originally calculated, but the blocks obtained though soil compaction in the laboratory presented uniform densities, appropriate for the purposes of such experiments. 


\section{Conclusion}

The laboratory technique of compressing wet sieved soil, used to obtain compacted soil blocks, was adequate and confirmed by tomographical analyses of samples that showed uniform bulk density distributions inside the blocks. A great variably was found within the investigated lines of pigeon pea (Cajanus cajan L.) in relation to their ability in transpassing soil layers of high bulk density and so promoting soil decompaction. Among the forty one evaluated lines, g5-94 and g8-95 were the most efficient to penetrate compact soil layers.

\section{Acknowledgments}

The authors wish to thank Unipasto (Association for Support to Research on Tropical Grass Improvement) CNPqNational Research Council of Brazil, for partially funding the project, and the Department of Crop Production, ESALQ, University of São Paulo, for the utilization of the greenhouse.

\section{References}

[1] W. Unger and T. C. Kaspar, "Soil compaction and root growth: a review," Agronomy Journal, vol. 86, pp. 759-766, 1994.

[2] M. W. Maughan, J. P. C. Flores, I. Anghinoni, G. Bollero, F. G. Fernández, and B. F. Tracy, "Soil quality and corn yield under crop-livestock integration in Illinois," Agronomy Journal, vol. 101, no. 6, pp. 1503-1510, 2009.

[3] E. L. Greacen and R. Sands, "Compaction of forest soils: a review," Australian Journal of Soil Research, vol. 18, no. 2, pp. 163-189, 1980.

[4] O. A. Camargo and L. R. F. Alleoni, "Compactação do solo e o desenvolvimento das plantas," Piracicaba: Escola Superior de Agricultura Luiz de Queiroz, p. 132, 1997.

[5] F. L. D. Cintra and J. Mielniczuk, "Potencial de algumas espécies vegetais para a recuperação de solos com propriedades físicas degradadas," Revista Brasileira de Ciência do Solo, vol. 7, pp. 197-201, 1983.

[6] S. A. Materechera, A. R. Dexter, and A. M. Alston, "Penetration of very strong soils by seedling roots of different plant species," Plant and Soil, vol. 135, no. 1, pp. 31-41, 1991.

[7] R. C. Alvarenga, L. M. Costa, W. Moura Filho, and A. J. Regazzi, "Crescimento de raízes de leguminosas em camadas de solo compactadas artificialmente," Revista Brasileira de Ciência do Solo, vol. 20, pp. 313-318, 1996.

[8] R. H. Da Silva and C. A. Rosolem, "Crescimento radicular de soja em razão da sucessão de cultivos e da compactação do solo," Pesquisa Agropecuaria Brasileira, vol. 37, no. 6, pp. 855860, 2002.

[9] R. Godoy, L. A. R. Batista, and G. F. Negreiros, "Avaliação agronômica e seleção de germoplasma de guandu forrageiro (Cajanus cajan (L.) Millsp)," Revista da Sociedade Brasileira de Zootecnia, vol. 23, pp. 742-749, 1994.

[10] R. Godoy, L. A. R. Batista, G. De Freitas Negreiros, and J. R. Porto de Carvalho, "Avaliação agronômica e seleção de germoplasma de guandu forrageiro (Cajanus cajan (L.) Millsp) proveniente da Índia," Revista Brasileira de Zootecnia, vol. 26, no. 3, pp. 447-453, 1997.

[11] R. Godoy, O. O. S. Bacchi, and F. A. Moreira, "Metodologias de laboratório para compactação de solos para análise de desenvolvimento de plantas," https://www.cppse.embrapa.
br/servicos/publicacaogratuita/documentos/Documentos74. pdf/view.

[12] L. F. Pires, J. R. De Macedo, M. D. De Souza, O. O. S Bacchi, and K. Reichardt, "Gamma-ray computed tomography to characterize soil surface sealing," Applied Radiation and Isotopes, vol. 57, no. 3, pp. 375-380, 2002.

[13] I. C. De Maria, O. M. Castro, and H. Souza Dias, "Atributos físicos do solo e crescimento radicular de soja em latossolo roxo sob diferentes métodos de preparo do solo," Revista Brasileira de Ciência do Solo, vol. 23, pp. 703-709, 1999. 


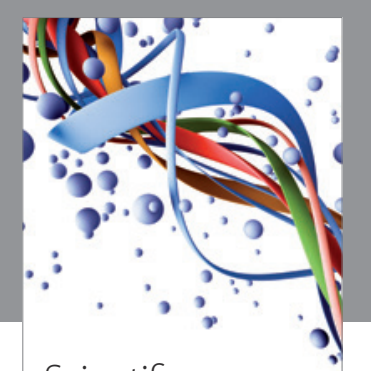

Scientifica
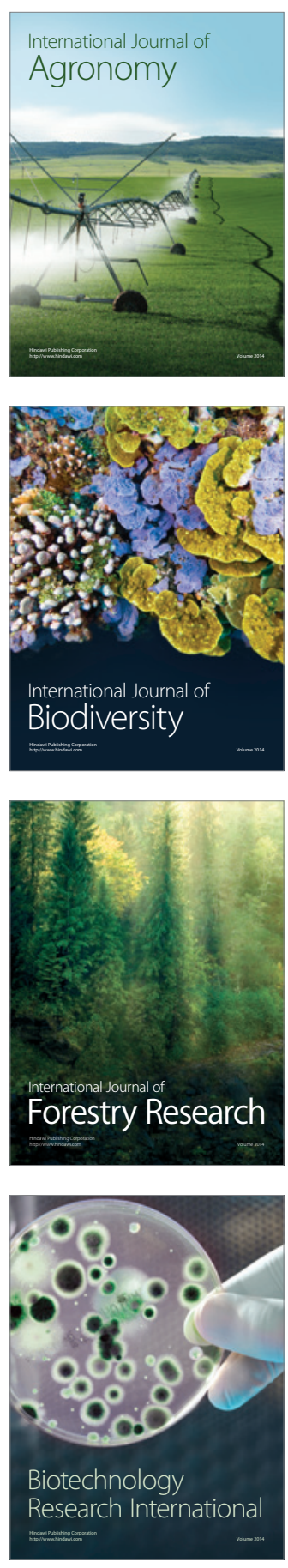
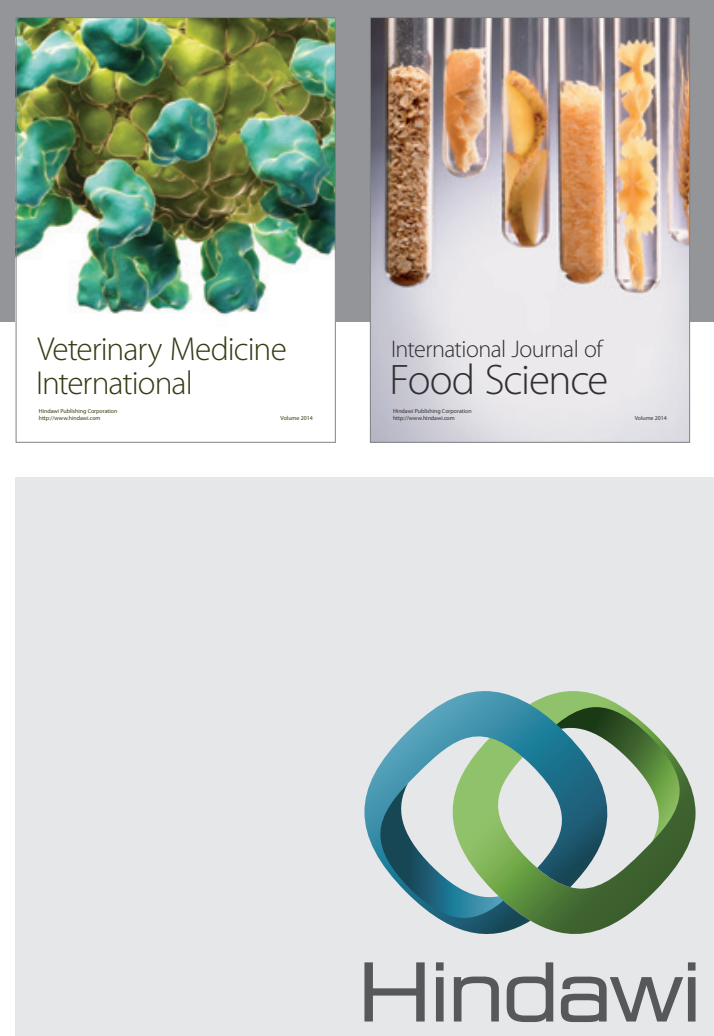

Submit your manuscripts at

http://www.hindawi.com
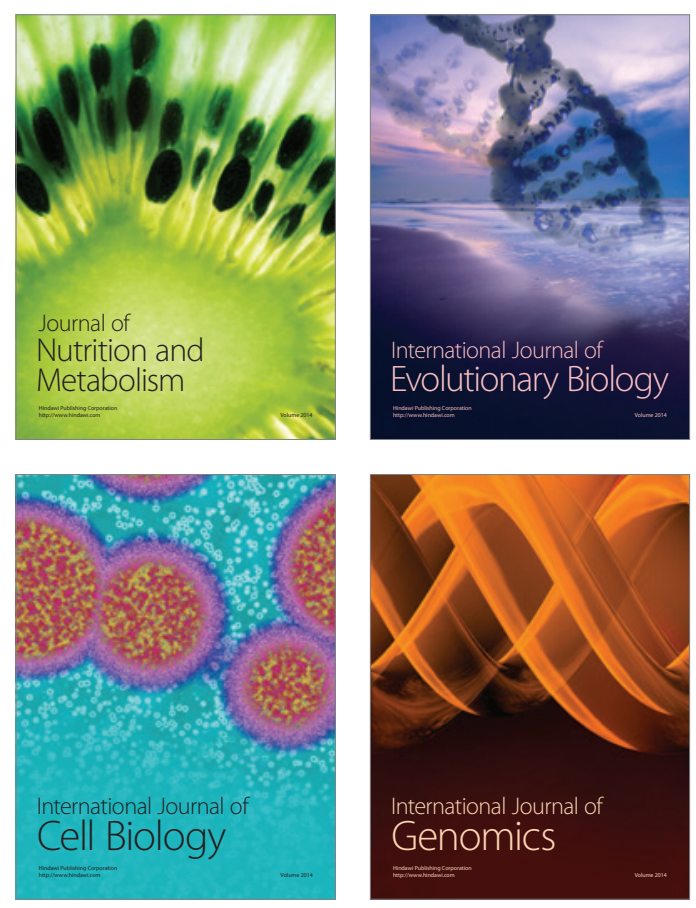
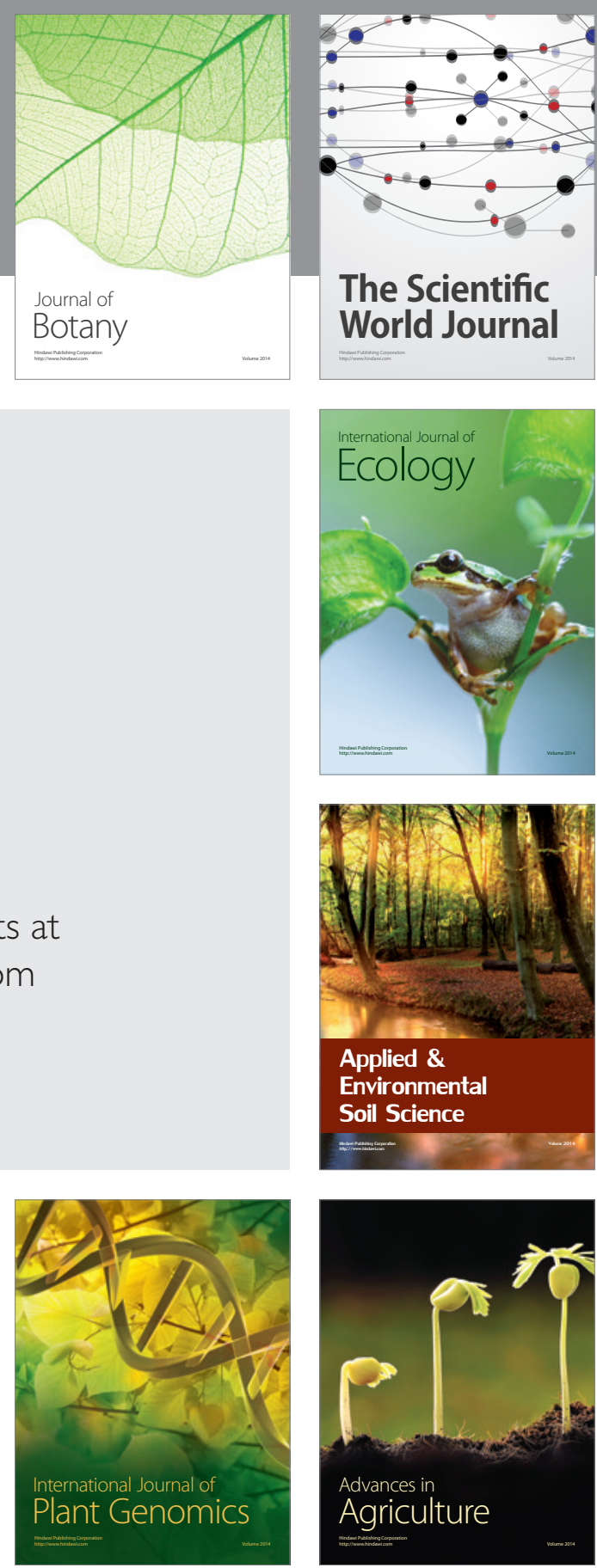

The Scientific World Journal
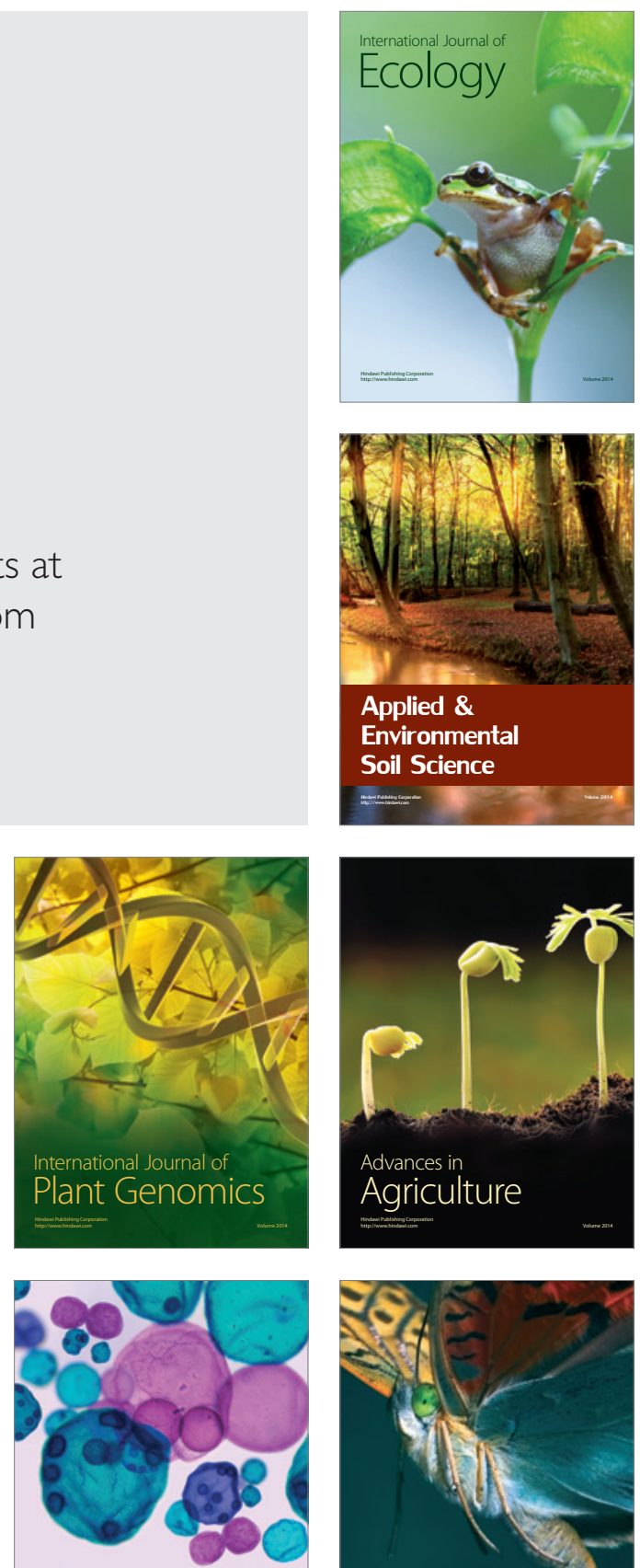

International Journal of Microbiology

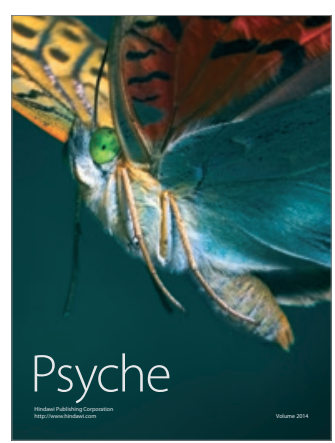

